\title{
The Effects of All-Trans Retinoic Acid on Vasculogenic Mimicry Formation Ability in CD133+ Glioma Stem Cells and Its Mechanisms
}

\author{
Ronghua Tang, Chen Liang*, Jian Shangguan, Shiwen Guo* \\ Department of Neurosurgery, First Affiliated Hospital of Xi'an Jiaotong University, Xi'an, China \\ Email: *liangchen_1042@126.com, *guoshiwen1962@126.com
}

How to cite this paper: Tang, R.H., Liang, C., Shangguan, J. and Guo, S.W. (2017) The Effects of All-Trans Retinoic Acid on Vasculogenic Mimicry Formation Ability in CD133+ Glioma Stem Cells and Its Mechanisms. Journal of Biosciences and Medicines, 5, 42-54.

https://doi.org/10.4236/jbm.2017.54005

Received: February 20, 2017

Accepted: April 27, 2017

Published: April 30, 2017

Copyright $\odot 2017$ by authors and Scientific Research Publishing Inc. This work is licensed under the Creative Commons Attribution International License (CC BY 4.0).

http://creativecommons.org/licenses/by/4.0/

\begin{abstract}
Objective: to investigate the effects of all-trans retinoic acid (ATRA) on vasculogenic mimicry formation in glioma stem cells. Methods: U87 stem cells were harvested through a suspension culture assay from the U87 cells, identified by CD133 and nestin, and counted by a flow cytometry. To investigate the VM formation ability of U87 stem cells with the treatment of various concentrations of ATRA, a Matrigel-based tube formation assay was used in the present study in vitro and tube-like structure (typical tube, TT; atypical tube AT) was observed and counted. Then the expressions of VEGF, VEGFR-2 and CD133 were measured throughout real time q-PCR, western blotting and immunofluorescence techniques. The data, presented as the mean \pm standard deviation, were analyzed using SPSS software. One-way analysis of variance was used to compare groups and Fisher's least significant difference tests were performed for subsequent comparisons between groups. $\mathrm{P}<0.01$ was considered to indicate a statistically significant difference. Results: Most of the harvested spheroid cells were positive for nestin and $88.4 \%$ were positive forCD133. The CD133+ U87 cells were cultured into tube like structure loaded on the top of Matrigel and the quantity of tubes was decreased under the treatment of ATRA. In addition, the expressions of VEGF, VEGFR-2 and CD133 were significantly reduced under the treatment of ATRA, particularly in the higher concentration groups $(20$ and $40 \mu \mathrm{mol}, \mathrm{P}<0.01)$. Conclusions: ATRA may inhibit the establishment of VM differing from stem cells in glioma, and these effects may attribute to the effects of ATRA's promotion of the differentiation of stem cells and/or down regulation of the expressions of proangiogenic factors VEGF and its receptor VEGFR-2. Thus, the results of the present study indicated a novel idea for the treatment of GBM and
\end{abstract}


enriched the anti-glioma mechanisms of ARTA.

\section{Keywords}

All-Trans Retinoic Acid, Vasculogenic Mimicry, Glioma Stem Cells

\section{Introduction}

Glioma is one of the most frequent types of tumors of the central nervous system in adults. The newly diagnosed high-grade gliomas-like glioblastomas (GBM) are currently treated with maximum safe surgery, followed by radiotherapy (RT), and/or systemic chemotherapy (CT) [1]. Due to the development of such standard treatment strategies, the percentage of patients alive two years after diagnosis has increased to $26 \%$ [2]. However, the majority of glioblastoma patients, particularly the elderly, succumb to the disease within a year [3], and this is not satisfactory. Thus, more effective treatment strategies which contain molecularly targeted therapies [4], immunotherapy [5], and gene therapy [6] are under investigation for patients with glioma [7].

GBM is a highly angiogenetic malignancy, so angiogenesis therapies have been considered having foreseeable positive effect on gliomatas [8]. Recent studies demonstrated that at least five mechanisms by which gliomas achieve neovascularization have been described: vascular co-option, angiogenesis, vasculogenesis, vascular mimicry (VM), and glioblastoma-endothelial cell trans differentiation [9]. However, due to the characteristics of VM consisting of tumor cells without any endothelial cells [10], traditional angiogenesis therapies [8] made poor contribution to inhibiting the formation of VM which was a new channel modality. In addition, evidences support that GBM contains glioma stem cells, which have the ability of self-renew and differentiate into multiple lineages and tumorigenesis, and so are considered the resource of the recurrent GBM [7] [11] [12]. The following studies indicated that tumor stem cells may be the origin of VM [13] [14]. Thus, novel treatment therapies aiming at the differentiation of stem cells or even the killing of stem cells were possible to reduce VM [15]. Meanwhile, all-trans retinoic acid (ATRA) was reported to be able to promote the proliferation and induce the differentiation of brain tumor stem cells [16] [17], and our early studies found that ATRA might influence the expression of VEGF which represents a major stimulatory factor for the initiation of angiogenesis [18], above all, it might be possible to use ATRA to inhibit the formation of VM. Therefore, the present study was aiming to investigate the effects of ATRA upon the VM formation of U87 stem cells and its possible mechanisms.

\section{Materials and Methods}

\subsection{Materials}

U-87MG human glioma cell lines were purchased from the Cell Resource Center 
of the Chinese Academy of Sciences (Shanghai, China).

\subsection{Culture and Identification of GSCs}

To collect Glioma stem cells (GSCs) U87 cells were resuspended and cultured [19]. U87 cells were cultured in an atmosphere of $5 \% \mathrm{CO}_{2}$ at $37^{\circ} \mathrm{C}$ and after $24 \mathrm{~h}$, well-growing cells at a density of $1 \times 10^{5} / \mathrm{ml}$ were seeded, suspended and cultured into flasks $\left(25 \mathrm{~cm}^{2}\right)$ that contained tumor stem cell medium consisting of Knock Out ${ }^{\mathrm{tw}}$ DMEM/F-12 (Gibco; USA) supplemented with B27 (2\%, Gibco, USA), $20 \mu \mathrm{g} / \mathrm{L}$ epidermal growth factor (EGF; Gibico; USA) and $20 \mu \mathrm{g} / \mathrm{L}$ basic fibroblast growth factor (bFGF; Gibco; USA). Half of the medium was replaced every 2 - 3 days, and suspended-growing cell spheroids were collected and seeded into a new flask with the same medium every 7days, then the new cells were resuspended and cultured. Cell spheroids were observed under a microscope. At last, immunofluorescence techniquewas used to identify the spheroid cells and flow cytometry technique to count CD133 positive cells. Cells were marked by nestin antibody (Santa; USA) and counted by CD133-PE (Miltenyi Blotec; Germany) using flow cytometry.

\subsection{Matrigel-Based Tube Formation Assay in Vitro}

A Matrigel-based tube formation assay [20] was used to obvious VM. Briefly, after Matrigel (BD) was warmed up at $4^{\circ} \mathrm{C}$ for 24 hours, $0.3 \mathrm{ml}$ of Matrigel was evenly plated to 24 -well plates which were precooled at $-20^{\circ} \mathrm{C}$ for at least $10 \mathrm{~min}$, and incubated for $30 \mathrm{~min}$ at $37^{\circ} \mathrm{C}$. Then stem cells $(1 \times 105)$ re-suspended with 1 $\mathrm{ml}$ of Knock Out ${ }^{\mathrm{m}}$ DMEM/F-12 (Gibco, USA) were loaded on the top of the Matrigel and incubated for 96 hours in a $5 \% \mathrm{CO}_{2}$ atmosphere at $37^{\circ} \mathrm{C}$. Each well was analyzed directly under an inverted microscope (Olympus, IX71). VM formation ability was determined by counting the quantity of tubes in a whole well at different time points of $0 \mathrm{~h}, 12 \mathrm{~h}, 24 \mathrm{~h}, 48 \mathrm{~h}$ and $96 \mathrm{~h}$. The tubes were divided into typical tubes (TT) and atypical tubes (AT). A TT means that the tube is a closed cavity, which is a loop structure or a polygon shape or even an irregular shape under a light microscope. On the other hand, an AT is just an open structure, which tends to become a cavity. A TT or an AT is considered as 1 counted tube.

\subsection{Real Time Quantitative Polymerase Chain Reaction (Real Time-qPCR)}

The tumor stem cell medium containing $0,5,10,20,40 \mu \mathrm{mol} / \mathrm{L}$ of ATRA was used to incubate the U87 stem cells $\left(1 \times 10^{5}\right)$ loaded on the top of the Matrigel as the tube formation assay before. After treating with ATRA $(0,5,10,20,40$ $\mu \mathrm{mol} / \mathrm{L}$ ) for $48 \mathrm{~h}$ cells were collected for isolating the total RNA of CD133, VEGF and VEGFR-2. In brief, Trizol (Life technologies; USA) chloroform, isopropanol and absolute ethyl alcohol (Sinopharm Chemical Reagent Co., Ltd; China) were used to extract total RNA from each group. Then RNA $(1 \mu \mathrm{g})$ was reverse transcribed with $5 \times$ Prime Script RT Master Mix Buffer ( $5 \mu \mathrm{L}$; Takara Biotechnology Co., Ltd., Dalian, China) and RNase Free $\mathrm{ddH}_{2} \mathrm{O}$ (up to $25 \mu \mathrm{L}$ ). qPCR was per- 
formed using a reaction system that contained SYBR Premix Ex Taq (10 $\mu \mathrm{L}$; Takara Biotechnology Co., Ltd.), PCR Forward Primer $(1 \mu \mathrm{L})$, PCR Reverse Primer $(1 \mu \mathrm{L})$, cDNA template $(1 \mu \mathrm{L})$ and $\mathrm{ddH}_{2} \mathrm{O}(7 \mu \mathrm{L})$ on a PCR instrument (Applied Biosystems; 9700; USA) and analyzed using a fluorescent quantitative PCR instrument (Applied Biosystems; 7500; USA). Gene expressions were compared using the cycle threshold $(\mathrm{Ct})$. Ct was defined using the following equation: $\Delta \mathrm{Ct}$ $=\mathrm{Ct}_{\text {Target }}-\mathrm{Ct}_{\beta \text {-actin }}$, where $\beta$-actin expression was used as the endogenous reference gene. Change in gene expression was evaluated using the $2^{-\Delta \Delta \mathrm{Ct}}$ method. All primers were designed and synthesized by Takara Biotechnology Co., Ltdasbelow: $\beta$-actin Forward: 5'-TGACGTGGACATCCGCAAAG-3'; $\beta$-actin Reverse: 5'-CTGGAAGGTGGACAGCGAGG-3';VEGF Forward: 5'-ACACACCCACCCACATACATACA-3'; VEGFReverse: 5'-AACTCAAGTCCACAGCAGTCAAA3'; VEGFR-2 Forward: 5'-ATGTACGGTCTATGCCATTCCTC-3'; VEGFR-2 Reverse: 5'-CTCTCTCCTCTCCCGACTTTGTT-3'; CD133 Forward: 5'-TGGCATCTTCTATGGTTTTGTGG-3'; CD133 Reverse: 5'-TCCTTGGTAGTGTTGTACTGGGC-3'.

\subsection{Western Blot}

The cells were harvested after cultured with ATRA on the top of Matrigel according to the tube formation assay for $48 \mathrm{~h}$. The cells were washed twice with PBS and then scraped in $100 \mu \mathrm{l}$ radioimmunoprecipitation assay lysis buffer (Beyotime Institute of Biotechnology. Inc.; China). Insoluble material was cleared out of the lysates by centrifugation. The total protein concentration was determined using a BCAprotein assay kit (Sigma-Aldrich. Inc.; USA) according to the instruction manual. And western blot method was used tomensurate the contents of target proteins in the total protein of each group. Briefly, samples(15 $\mu \mathrm{l} /$ well) boiled with $2 \times$ SDS-PAGE sample loading buffer for $5 \mathrm{~min}$ were resolved by SDS-PAGE (Tanon.Inc.; EPS-200; Shanghai, China) and then transferred to polyvinylidene fluoride membranes (PVDF membranes; Millipore; USA). The membranes were blocked in the BSA (5\%; Sigma-Aldrich. Inc., USA) and then washed three times for $5 \mathrm{~min}$ using Tris-buffered saline containing $0.02 \%$ Tween 20 (TBST; Sinopharm Chemical Reagent Co., Ltd; China). The membranes were incubated with rabbit anti-VGEF(dilution, 1:1000; Abcam, UK), rabbit antiVGEFR-2 (dilution, 1:1000; Abcam, UK), CD133 antibody (dilution, 1:5000; Miltenyi Blotec Co., Germany) and GAPDH antibody (dilution, 1:5000; cat. no. ap0063) at $4^{\circ} \mathrm{C}$ and stayed overnight, all antibodies were diluted with TBST. The membranes washed by TBST three times were incubated with a secondary antibody conjugated to horseradish peroxidase (dilution, 1:3000; The-rmo Fisher Scientific, Pittsburgh, PA, USA) for 1 hat last, Membranes were developed and fixed in a dark room using X-ray film (Eastman Kodak Company, USA).

\subsection{Immunofluorescence Analysis}

To perform target products, immunofluorescence assay was used. In brief, according to the Matrigel-based tube formation assay, cells were cultured on the 
top of the Matrigel with different concentrations of ATRA for 48h. Then cells were fixed with $4 \%$ paraformaldehyde and then blocked with 5\% BSA. Overnight staining at indoor temperature with antibodies (dilution, 1:100) above, fluorescent secondary antibodies (dilution, 1:100) marked with FITC were put into the related groups at $37^{\circ} \mathrm{C}$ and kept for $30 \mathrm{~min}$. Fluorescent-labeled slides were examined under a fluorescent microscope (Olympus, Japan). Antibodies contained anti-VEGF, anti-VEGFR-2 and CD133 used in the western blotting.

\subsection{Statistical Analysis}

The data are presented as the mean \pm standard deviation and were analyzed using SPSS software, version 20.0 (SPSS, Inc., Chicago, IL, USA). One-way analysis of variance was used to compare groups and Fisher's least significant difference tests were performed for subsequent comparisons between groups. $\mathrm{P}<0.01$ was considered to indicate a statistically significant difference.

\section{Results}

\subsection{U87 Sphere Cells Show the Properties of Glioma Stem Cells}

In the present assays, the U87 cells were cultured like a sphere.CD133 and nestin were markers of golima stem cells as reported [21]. As shown in Figure 1, the majority of harvested sphere cells were positive for nestin, and $88.4 \%$ were positive for CD133.

\subsection{ARTA Significantly Inhibits the Tube Formation Ability of U87 Stem Cells}

In order to test the tube formation ability of U87 stem cells, a Martrigel-based assay was completed. The results (Figure 2) showed that cells began to spread

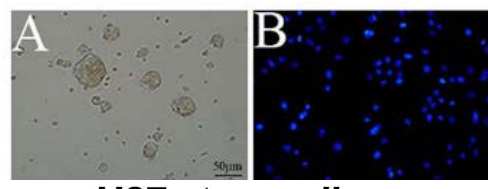

U87 stem cells

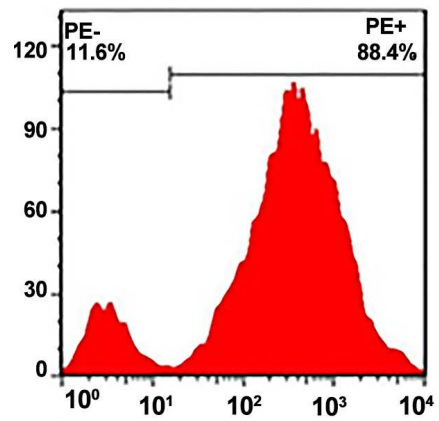

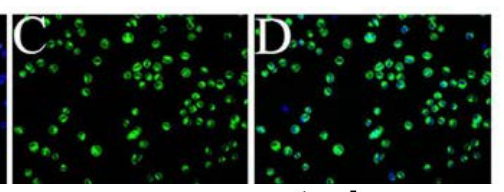

control

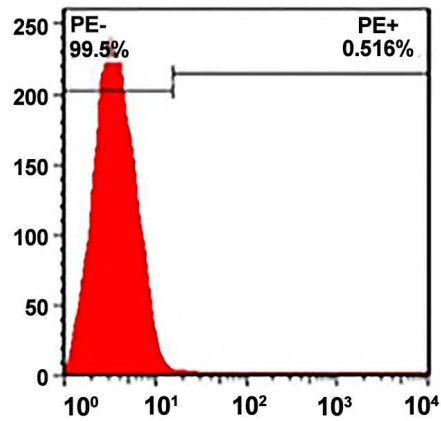

(E)

Figure 1. U87 stem cells. U87 cells were cultured like a sphere (A, scale $=50 \mu \mathrm{m})$. DAPI (B, blue) and nestin (C, green) were identified under a fluorescence microscope. (B) and (C) were overlapped into (D) Cells were counted under a flow cytometry by CD133, and $88.4 \%$ were positive for CD133 (E). 
around, connect with the neighbor cells rapidly in the first $24 \mathrm{~h}$ when typical tubes (TT, 65.0 $\pm 4.6 /$ well) and atypical tubes (AT, $13 \pm 4.0 /$ well) were observed. However, new tubes were nearly not observed at $48 \mathrm{~h}(78.7 \pm 2.3 /$ well $)$ and $96 \mathrm{~h}$ $(82.3 \pm 5.9 /$ well $)$ compared with the tubes at $24 \mathrm{~h}(78.3 \pm 8.2 /$ well $)$. In the following treatment of ATRA $(0,5,10,20,40 \mu \mathrm{mol} / \mathrm{L} ; 0 \mu \mathrm{mol} / \mathrm{L}$ for control group) on U87 stem cells for $48 \mathrm{~h}$, the tube quantity per well of high concentration treatment groups was decreased obviously, compared with the control group $(\mathrm{P}<$ 0.01 ), particularly in $40 \mu \mathrm{mol} / \mathrm{L}$ concentration group, tubes were hardly observed (Figure 2).

\subsection{ARTA Significantly Inhibits the Expressions of VEGF, CD133 and VEGFR-2}

As performed in Figure 3(A), the mRNA expressions of VEGF were all significantly down-regulated $(\mathrm{P}<0.01$, vs. control group) but the $5 \mu \mathrm{mol} / \mathrm{L}$ group ( $\mathrm{p}=$ 0.318 , vs. control group). The statistically difference between $5 \mu \mathrm{mol} / \mathrm{L}$ group and $10 \mu \mathrm{mol} / \mathrm{L}$ group was not identified on the expression of CD133 mRNA $(\mathrm{P}=$ 0.447), either.

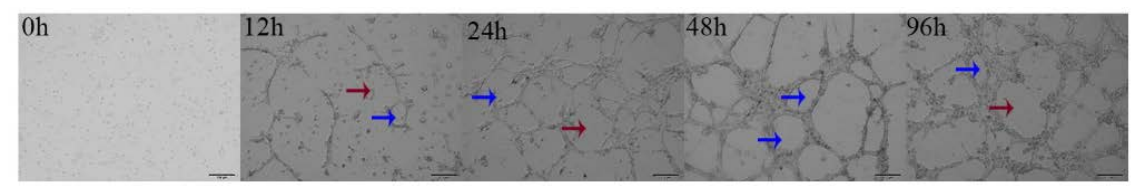

(A)

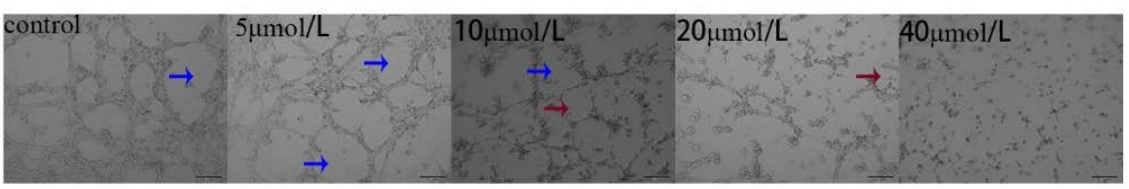

(B)

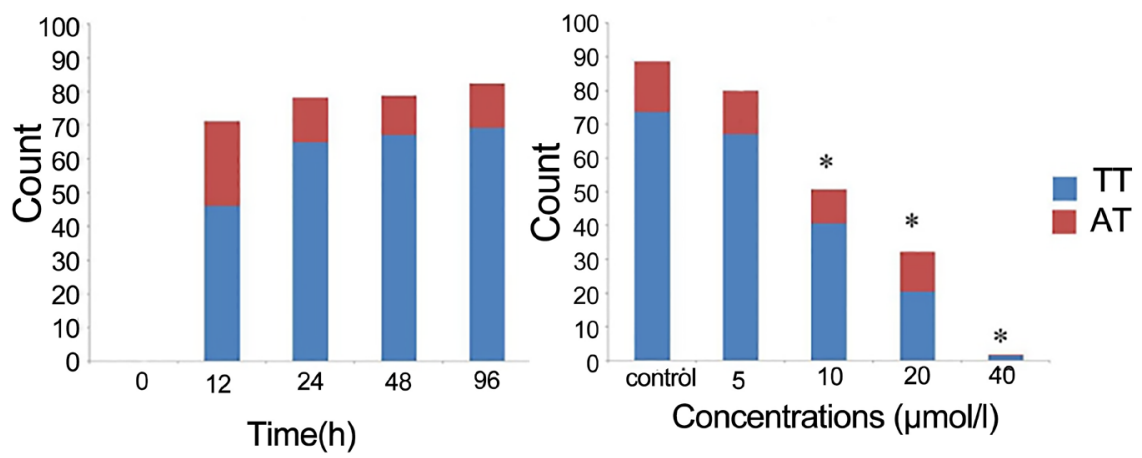

(C)

Figure 2. Tube formation ability of U87 stem cells. The ability was determined by a Matrigel-based tube formation assay. Total quantity of Typical tubes (TT; blue arrow) and atypical tubes (AT; red arrow) were counted in a hole well at different times (A) and with treatment of various concentrations (control group $=0 \mu \mathrm{mol} / \mathrm{L}, 5,10,20,40 \mu \mathrm{mol} / \mathrm{L}$ ) of ATRA for $48 \mathrm{~h}$ (B). A TT or an AT is considered as 1 counted tube. The values according to the counted tubes (both TTs and ATs) are presented as the mean \pm standard deviation according. $\left({ }^{*} \mathrm{P}<0.01\right.$, vs. control group; $\left.\mathrm{n}=3\right)$. ATRA, all-trans retinoic acid. 


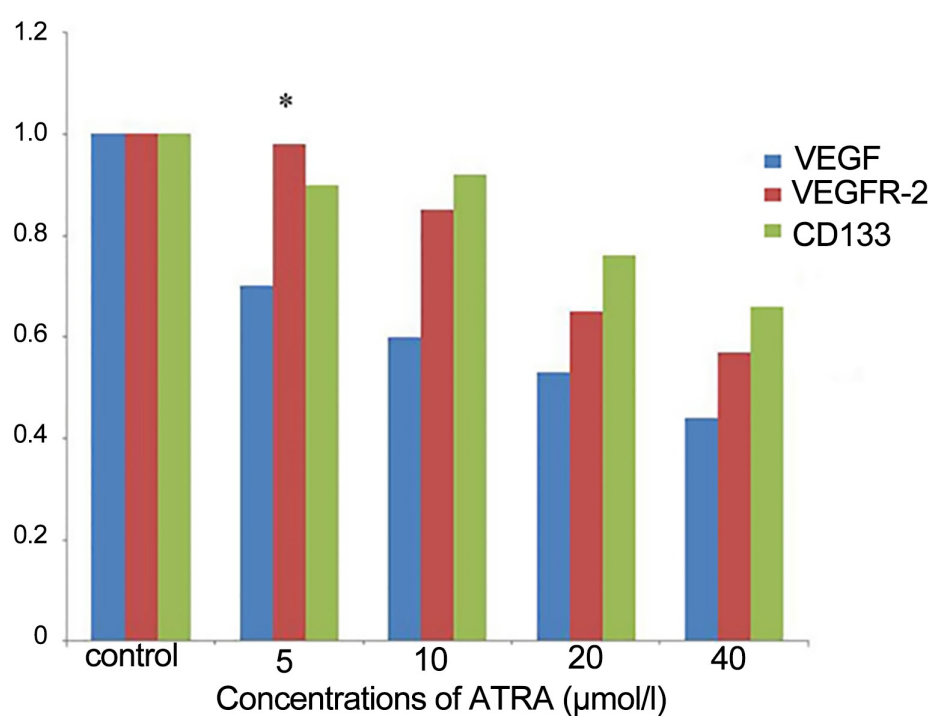

(A)

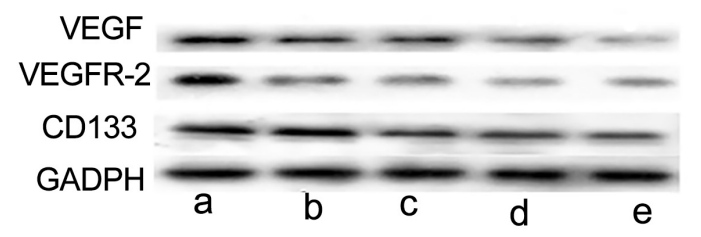

(B)
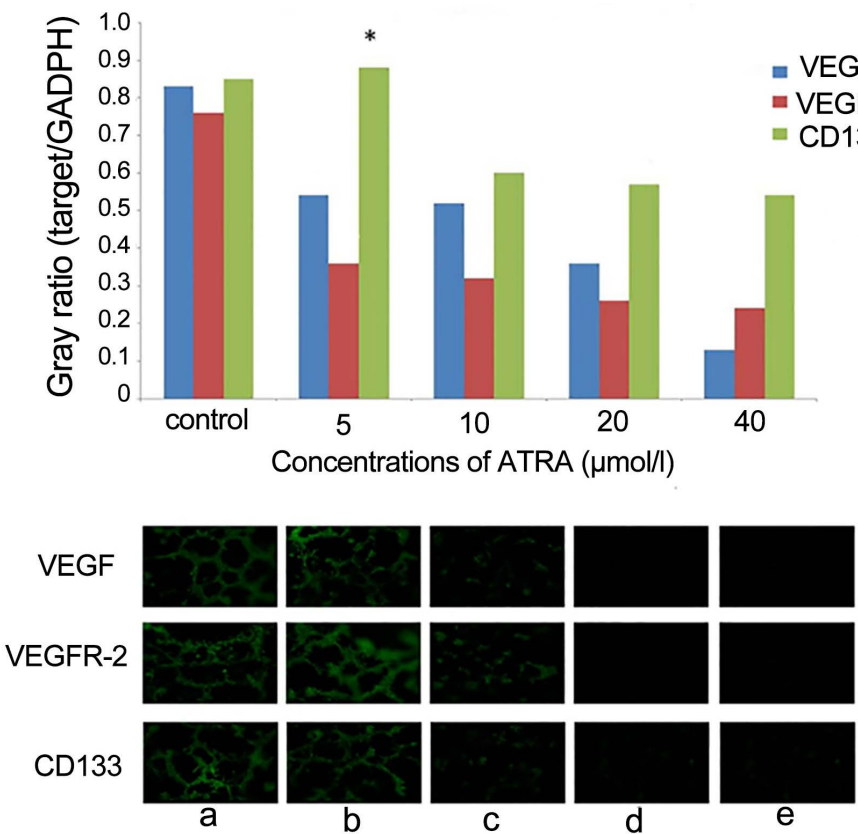

(C)

Figure 3. The expressions of VEGF and VEGFR-2 and CD133 with treatment of various concentrations of ATRA.(A)Effects of ATRA on the mRNA expression levels of VEGF, VEGFR-2 and CD133 ( ${ }^{*} \mathrm{p}=0.318$, vs. control group; $\mathrm{P}<0.01$, other groups vs. control group); (B) Effects of ATRA on the protein expressions of the VEGF, VEGFR-2 and $\mathrm{CD} 133\left({ }^{*} \mathrm{p}=0.228\right.$, vs. BC group; $\mathrm{P}<0.01$, other groups vs. control group); (C) The immunofluorescence expressions of VEGF, VEGFR2 and CD133 with the treatment of ATRA. ( $\mathrm{a}=$ control group, $\mathrm{b}=5 \mu \mathrm{mol} / \mathrm{L}, \mathrm{c}=10 \mu \mathrm{mol} / \mathrm{L}, \mathrm{d}=20 \mu \mathrm{mol} / \mathrm{L}, \mathrm{e}=40 \mu \mathrm{mol} / \mathrm{L}$ ). 
Meanwhile, the results (Figure 3(B)) of western blotting indicated that protein expression levels of the three target markers were totally decreased as the similar trend with the mRNA expression levels, particularly the higher concentration groups $(20,40 \mu \mathrm{mol} / \mathrm{L} ; \mathrm{P}<0.01$, vs. control group). However, the influence in the protein expressions of VEGF and VEGFR-2 between the lower concentration groups $(5,10 \mu \mathrm{mol} / \mathrm{L})$ was not distinguished by the statistically method $(\mathrm{P}>0.05)$.

At last, the results of immunofluorescence tests (Figure 3(C)) showed that the expression levels of all the three targets in higher concentration groups were down-regulated under the fluorescence microscope compared with the control group and lower concentration groups.

\section{Discussion}

Since VM was found and described as a new vascular channel formation without any endothelial cell in human melanoma at the first time in 1999 [10], this novel tube was described in a lot of tumors, including lung cancer [22], glioblastoma [23], breast cancer [24] bladder cancer [25], ovarian cancer [26], hepatocellular cancer [27], gastric cancer [28], etc. As is reported, VM can transport fluid from leaky vessels and/or connect with endothelial-lined vasculature for rapidly growing tumors [29], thereby, combined treatments between anti-angiogenesis and anti-VM are necessary in the treatment of tumors. However, how to inhibit VM was described poorly. Increasing evidence suggests that cancer stem cells (CSCs) are involved in VM formation [24] [26] [27] [30] [31]. The present study showed that the CD133+ U87 cells could be cultured into tube-like structures and ATRA could significantly inhibit the formation of these tubes in a dose-dependent manner in vitro, indicating that ATRA may be an inhibitor of VM. To describe how it came, the following studies focused on the expressions of CD133, VEGF and VEGFR-2, particularly on the VEGF/VEGFR2axis that was tested in gliomas to form VM for the first time. Expressions of CD133, VEGF and VEGFR2 were tested and results performed that the expression levels of the three targets were obviously decreased, particularly in the high concentration groups.

ATRA, as a biologically active metabolite of vitamin A, was widely used in the treatment of leukemia at first [32], and then ATRA was beginning to be used to cure other tumors like gliomas [33] [34], lung cancers [35], and cutaneous cancers [36] some studies [37] [38] and our previous studies found that ATRA may inhibit migration, invasion and proliferation, and promote differentiation and apoptosis in glioma cells. While being used to treat glioma stem cells, it seemed that ATRA could still promote differentiation, but the differentiation was incomplete, terminal differentiation could not be achieved and tumor cells could be formed again [16]. Thus, the present study mainly aimed at inhibiting the formation of VM in gliomas through ATRA curing glioma stem cells. The result performed that the capacity of CD133+ U87 stem cells to form VM tubes was decreased under the treatment of ATRA and even disappeared under the higher 
concentration of ATRA ( $40 \mu \mathrm{mol} / \mathrm{L})$, which agreed with the previous results [39].

However, the mechanisms by which ATRA inhibited glioma stem cells remain unclear. According to our test results, it seemed that glioma stem cells may be the resource of VM and that ATRA may inhibit VM occurring through proposing differentiation of glioma stem cells and/or down regulating key factors of tube formation. Firstly, as a marker of stem cells, CD133 was also used in gliomas to identify stem cells [21], and previous studies in melanoma [13] and mammary cancer [40] illustrated that CD133+ cancer cells could differentiate into VM to drive tumor growth. In our present studies, CD133+ U87 stem cells were cultured into VM, and ATRA significantly inhibited the ability of those cells to form VM as well as decreased the expression levels of CD133. It indicated that ATRA may promote differentiation of glioma to inhibit VM. Though CD133 was negative under the immunofluorescence tests, the remaining expression of CD133 at transcriptional and translational levels in our study might be one of the reasons why ATRA inhibited glioma stem cells incompletely [16], which needs to be proved in future studies. Secondly, VEGF was considered playing an important role in the induction of nonendothelial organs such as livers and pancreas [41], which may also be necessary for the formation of VM [42]. And VEGFR-2, as the main receptor of VEGF's pro-angiogenic signal transducer [43], also plays an emphatic role in VM formation [44] [45]. In our present study, we found that ATRA could decrease the expression levels of both VEGF and VEGFR-2 during the treatment of glioma stem cells to form VM for the first time. As is well known, the PLC $\gamma$-PKC-MAPK pathway is highly activated in VEGF-bound VEGFR-2 and used as a crucial signal for endothelial proliferation [46]. Thus, ATRA may make a contribution to blocking the PLC $\gamma$ PKC-MAPK pathway in glioma stem cells to inhibit VM. In the meantime, recent therapies [47] demonstrated that only "early" vessels were highly responsive to anti-VEGF/VEGFR therapy, VM thereby might be consigned to the "early" vessels and ATRA might be an effective drug for anti-VEGF/VEGFR. However, further studies are still needed. Above all, ARTA may inhibit VM through promoting differentiation of glioma stem cells and/or down-regulating the expressions of both VEGF and its receptor VEGFR-2.

In conclusion, the present study identified that ATRA treatment may inhibit the establishment of VM differing from stem cells in gliomas, and these effects may attribute to the effects of ATRA on promotion of the differentiation of stem cells and/or on the down regulation of the expressions of proangiogenic factors VGEF and its receptor VGEFR-2. Thus, the results of the present study indicated a novel idea for the treatment of GBM and enriched the anti-glioma mechanisms of ARTA. At last we support that ATRA can serve as an adjuvant drug in glioma therapy and even in some kinds of other tumors which contain VM after a series of further studies.

\section{Acknowledgements}

This work was supported by a grant from institutional science foundation of the 
First Affiliated Hospital of Xi' an Jiao tong University (No. 2014YK12).

\section{References}

[1] Le Rhun, E., Rhun, E.L., Taillibert, S. and Chamberlain, M.C. (2015) The Future of High-Grade Glioma: Where We Are and Where Are We Going. Surgical Neurology International, 6, S9-S44. https://doi.org/10.4103/2152-7806.151331

[2] Clarke, J., Butowski, N. and Chang, S. (2010) Recent Advances in Therapy for Glioblastoma. Archives of Neurology, 67, 279-283. https://doi.org/10.1001/archneurol.2010.5

[3] Louis, D.N., Ohgaki, H., Wiestler, O.D., Cavenee, W.K., Burger, P.C. and Jouvet, A. (2007) The 2007 WHO Classification of Tumors of the Central Nervous System. Acta Neuropathologica, 114, 97-109. https://doi.org/10.1007/s00401-007-0243-4

[4] Bai, R.Y., Staedtke, V. and Riggins, G.J. (2011) Molecular Targeting of Glioblastoma: Drug Discovery and Therapies. Trends in Molecular Medicine, 17, 301-312.

[5] Vauleon, E., Avril, T., Collet, B., Mosser, J. and Quillien, V. (2010) Overview of Cellular Immunotherapy for Patients with Glioblastoma. Clinical and Developmental Immunology, 2010, Article ID: 689171. https://doi.org/10.1155/2010/689171

[6] Mohyeldin, A. and Chiocca, E.A. (2012) Gene and Viral Therapy for Glioblastoma: A Review of Clinical Trials and Future Directions. The Cancer Journal, 18, 82-88. https://doi.org/10.1097/ppo.0b013e3182458b13

[7] Wilson, T.A., Karajannis, M.A. and Harter, D.H. (2014) Glioblastoma Multiforme: State of the Art and Future Therapeutics. Surgical Neurology International, 5, 64.

[8] Folkman, J. (1971) Tumor Angiogenesis: Therapeutic Implications. The New England Journal of Medicine, 285, 1182-1186. https://doi.org/10.1056/NEJM197111182852108

[9] Hardee, M.E. and Zagzag, D. (2012) Mechanisms of Glioma-Associated Neovascularization. American Journal of Pathology, 181, 1126-1141.

[10] Maniotis, A.J., Folberg, R., Hess, A., Seftor, E.A., et al. (1999) Vascular Channel Formation by Human Melanoma Cells in Vivo and in Vitro: Vasculogenic Mimicry. American Journal of Pathology, 155, 739-752.

[11] Wang, J., Wakeman, T.P., Lathia, J.D., et al. (2010) Notch Promotes Radio Resistance of Glioma Stem Cells. Stem Cells, 28, 17-28.

[12] Chen, J., Li, Y., Yu, T.S., McKay, R.M., Burns, D.K., Kernie, S.G., et al. (2012) A Restricted Cell Population Propagates Glioblastoma Growth after Chemotherapy. Nature, 488, 522-526. https://doi.org/10.1038/nature11287

[13] Lai, C.Y., Schwartz, B.E. and Hsu, M.Y. (2012) CD133+ Melanoma Subpopulations Contribute to Perivascular Niche Morphogenesis and Tumorigenicity through Vasculogenic Mimicry. Cancer Research, 72, 5111-5118. https://doi.org/10.1158/0008-5472.CAN-12-0624

[14] El Hallani, S., Boisselier, B., Sanson, M., et al. (2010) A New Alternative Mechanism in Glioblastoma Vascularization: Tubular Vasculogenic Mimicry. Brain, 133, 973982. https://doi.org/10.1093/brain/awq044

[15] Seftor, R.E., Hess, A.R., Hendrix, M.J., et al. (2012) Tumor Cell Vasculogenic Mimicry: From Controversy to Therapeutic Promise. American Journal of Pathology, 181,1115-1125.

[16] Niu, C.S., Li, M.W., Ni, Y.F., et al. (2010) Effect of All-Trans Retinoic Acid on the Proliferation and Differentiation of Brain Tumor Stem Cells. Journal of Experimental \& Clinical Cancer Research, 29, 113. 
https://doi.org/10.1186/1756-9966-29-113

[17] Campos, B., Wan, F., Farhadi, M., et al. (2010) Differentiation Therapy Exerts Antitumor Effects on Stem-Like Glioma Cells. Clinical Cancer Research, 16, 27152728. https://doi.org/10.1158/1078-0432.CCR-09-1800

[18] Thaker, N.G. and Pollack, I.F. (2009) Molecularly Targeted Therapies for Malignant Glioma: Rationale for Combinatorial Strategies. Expert Review of Neurotherapeutics, 9, 1815. https://doi.org/10.1586/ern.09.116

[19] Baowei, J., Qianxue, C., Baohui, L., Liquan, W., Daofeng, T., Zhentao, G. and Wei, Y. (2013) Glioma Stem Cell-Targeted Dendritic Cells as a Tumor Vaccine against Malignant Glioma. Yonsei Medical Journal, 54, 92-100. https://doi.org/10.3349/ymj.2013.54.1.92

[20] Francescone, R.A. III, Faibish, M. and Shao, R. (2011) A Matrigel-Based Tube Formation Assay to Assess the Vasculogenic Activity of Tumor Cells. Journal of Visualized Experiments, No. 55, e3040. https://doi.org/10.3791/3040

[21] David, L.S., Daniel, L. and Tyler, E.M. (2014) Brain Tumor Stem Cells: Molecular Characteristics and Their Impact on Therapy. Molecular Aspects of Medicine, 39, 82-101.

[22] Misra, R.M., Bajaj, M.S. and Kale, V.P. (2012) Vasculogenic Mimicry of HT1080 Tumor Cells in Vivo: Critical Role of HIF-1 Alpha-Neuropilin-1 Axis. PLoS ONE, 7, e50153.

[23] Sharma, N., Seftor, R.E., Seftor, E.A., et al. (2002) Prostatic Tumor Cell Plasticity Involves Cooperative Interactions of Distinct Phenotypic Subpopulations: Role in Vasculogenic Mimicry. Prostate, 50, 189-201. https://doi.org/10.1002/pros.10048

[24] Zhang, D., Sun, B., Chi, J., et al. (2014) Twist 1 Expression Induced by Sunitinib Accelerates Tumor Cell Vasculogenic Mimicry by Increasing the Population of CD133+ Cells in Triple-Negative Breast Cancer. Molecular Cancer, 13, 207. https://doi.org/10.1186/1476-4598-13-207

[25] Fujimoto, A., Onodera, H., Mori, A., et al. (2006) Tumour Plasticity and Extravascular Circulation in ECV304 Human Bladder Carcinoma Cells. Anticancer Research, 26, 59-69. https://doi.org/10.1586/14737140.6.1.59

[26] Su, M., Wei, W., Xu, X., et al. (2011) Role of hCG in Vasculogenic Mimicry in OVCAR-3 Ovarian Cancer Cell Line. International Journal of Gynecological Cancer, 21, 1366-1374. https://doi.org/10.1097/IGC.0b013e31822c7529

[27] Liu, W.B., Xu, G.L., Jia, W.D., et al. (2011) Prognostic Significance and Mechanisms of Patterned Matrix Vasculogenic Mimicry in Hepatocellular Carcinoma. Medical Oncology, 28, 228-238. https://doi.org/10.1007/s12032-010-9706-x

[28] Li, M., Gu, Y., Zhang, Z., et al. (2010) Vasculogenic Mimicry: A New Prognostic Sign of Gastric Adenocarcinoma. Pathology and Oncology Research, 16, 259-266. https://doi.org/10.1007/s12253-009-9220-7

[29] Kirschmann, D.A., Seftor, E.A., Hardy, K.M., Seftor, R.E.B. and Hendrix, M.J.C. (2012) Molecular Pathways: Vasculogenic Mimicry in Tumor Cells: Diagnostic and Therapeutic Implications. Clinical Cancer Research, 18, 2726-2732. https://doi.org/10.1158/1078-0432.CCR-11-3237

[30] Valyi-Nagy, K., Kormos, B., Ali, M., Shukla, D. and Valyi-Nagy, T. (2012) Stem Cell Marker CD271 Is Expressed by Vasculogenic Mimicry-Forming Uveal Melanoma Cells in Three-Dimensional Cultures. Molecular Vision, 18, 588-592.

[31] Scully, S., Francescone, R., Faibish, M., et al. (2012) Trans-Differentiation of Glioblastoma Stem-Like Cells into Mural Cells Drives Vasculogenic Mimicry in Glioblastomas. Journal of Neuroscience, 32, 12950-12960. 
https://doi.org/10.1523/JNEUROSCI.2017-12.2012

[32] Asou, N. (2007) All-Trans Retinoic Acid in the Treatment of Acute Promyelocytic Leukemia. Internal Medicine, 46, 91-93. https://doi.org/10.2169/internalmedicine.46.1780

[33] Le Doze, F., Debruyne, D., Albessard, F., Barre, L. and Defer, G.L. (2000) Pharmacokinetics of All-Trans Retinoic Acid, 13-Cis Retinoic Acid, and Fenretinide in Plasma and Brain of Rat. Drug Metabolism \& Disposition, 28, 2058-2088.

[34] Karmakar, S., Banik, N.L. and Ray, S.K. (2008) Combination of All-Trans Retinoic Acid and Paclitaxel-Induced Differentiation and Apoptosis in Human Glioblastoma U87MG Xenografts in Nude Mice. Cancer, 112, 596-607. https://doi.org/10.1002/cncr.23223

[35] Moro, M., Bertolini, G., Pastorino, U., Roz, L. and Sozzi, G. (2015) Combination Treatment with All-Trans Retinoic Acid Prevents Cisplatin-Induced Enrichment of CD133+ Tumor-Initiating Cells and Reveals Heterogeneity of Cancer Stem Cell Compartment in Lung Cancer. Journal of Thoracic Oncology, 10, 1027-1036. https://doi.org/10.1097/JTO.0000000000000563

[36] Zhang, M.L., Tao, Y., Zhou, W.Q., et al. (2014) All-Trans Retinoic Acid Induces Cell-Cycle Arrest in Human Cutaneous Squamous Carcinoma Cells by Inhibiting the Mitogen-Activated Protein Kinase-Activated Protein 1 Pathway. Clinical and Experimental Dermatology, 39, 354-360. https://doi.org/10.1111/ced.12227

[37] Gumireddy, K., Sutton, L.N., Phillips, P.C. and Reddy, C.D. (2003) All-Trans-Retinoic Acid-Induced Apoptosis in Human Medulloblastoma: Activation of Caspase3/Poly(ADP-Ribose) Polymerase 1 Pathway. Clinical Cancer Research, 8, 40524059.

[38] Chen, P.H., Shih, C.M., Chang, W.C., et al. (2014) MicroRNA-302b-Inhibited E2F3 Transcription Factor Is Related to All Trans Retinoic Acid-Induced Glioma Cell Apoptosis. Journal of Neurochemistry, 131, 731-742. https://doi.org/10.1111/jnc. 12820

[39] Ling, G., Liu, Y., Ke, Y., et al. (2015) All-Trans Retinoic Acid Impairs the Vasculogenic Mimicry Formation Ability of U87 Stem-Like Cells through Promoting Differentiation. Molecular Medicine Reports, 12, 165-172.

[40] Witkiewicz, H., Oh, P. and Schnitzer, J.E. II (2013) Capsular Vaso-Mimicry Formed by Transgenic Mammary Tumor Spheroids Implanted Ectopically into Mouse Dorsal Skin Fold: Implications for Cellular Mechanisms of Metastasis. Version 2. F1000 Research, 2, 9. https://doi.org/10.12688/f1000research.2-9.v1

[41] Haigh, J.J. (2008) Role of VEGF in Organogenesis. Organogenesis, 4, 247-256. https://doi.org/10.4161/org.4.4.7415

[42] Pitzer, M.R., Sortwell, C.E., Daley, B.F., et al. (2003) Angiogenic and Neurotrophic Effects of Vascular Endothelial Growth Factor (VEGF165): Studies of Grafted and Cultured embryonic Ventral Mesencephalic Cells. Experimental Neurology, 182, 435-445.

[43] Shibuya, M. (2011) Vascular Endothelial Growth Factor (VEGF) and Its Receptor (VEGFR) Signaling in Angiogenesis. Genes Cancer, 2, 1097-1105. https://doi.org/10.1177/1947601911423031

[44] Yao, X., Ping, Y., Bian, X., et al. (2013) Vascular Endothelial Growth Factor Receptor 2 (VEGFR-2) Plays a Key Role in Vasculogenic Mimicry Formation, Neovascularization and Tumor Initiation by Glioma Stem-Like Cells. PLoS ONE, 8, e57188. https://doi.org/10.1371/journal.pone.0057188

[45] Francescone, R., Scully, S., Bentley, B., Yan, W., Taylor, S.L., Oh, D., Moral, L. and 
Shao, R. (2012) Glioblastoma-Derived Tumor Cells Induce Vasculogenic Mimicry through Flk-1 Protein Activation. The Journal of Biological Chemistry, 287, 24821 24831. https://doi.org/10.1371/journal.pone.0057188

[46] Nagy, J.A. and Dvorak, H.F. (2012) Heterogeneity of the Tumor Vasculature: The Need for New Tumor Blood Vessel Type-Specific Targets. Clinical and Experimental Metastasis, 29, 657-662. https://doi.org/10.1007/s10585-012-9500-6

[47] Sitohy, B., Nagy, J.A., Jaminet, S.C. and Dvorak, H.F. (2011) Tumor-Surrogate Blood Vessel Subtypes Exhibit Differential Susceptibility to Anti-VEGF Therapy. Cancer Research, 71, 7021-7028. https://doi.org/10.1158/0008-5472.CAN-11-1693

Submit or recommend next manuscript to SCIRP and we will provide best service for you:

Accepting pre-submission inquiries through Email, Facebook, LinkedIn, Twitter, etc. A wide selection of journals (inclusive of 9 subjects, more than 200 journals)

Providing 24-hour high-quality service

User-friendly online submission system

Fair and swift peer-review system

Efficient typesetting and proofreading procedure

Display of the result of downloads and visits, as well as the number of cited articles

Maximum dissemination of your research work

Submit your manuscript at: http://papersubmission.scirp.org/

Or contact jbm@scirp.org 